\title{
A Wasted Eden: Colonial Water Management and Ecological Change in Kitui, Kenya 1948-63
}

James Parker

\section{Q OpenEdition \\ 1 Journals}

\section{Electronic version}

URL: https://journals.openedition.org/eastafrica/1346

DOI: 10.4000/eastafrica.1346

ISSN: 2790-1076

Publisher

IFRA - Institut Français de Recherche en Afrique

\section{Electronic reference}

James Parker, "A Wasted Eden: Colonial Water Management and Ecological Change in Kitui, Kenya 1948-63", Les Cahiers d'Afrique de l'Est / The East African Review [Online], 55 | 2020, Online since 16 November 2020, connection on 09 December 2021. URL: http://journals.openedition.org/eastafrica/ 1346 ; DOI: https://doi.org/10.4000/eastafrica.1346

This text was automatically generated on 9 December 2021.

Les Cahiers d'Afrique de l'Est / The East African Review 


\title{
A Wasted Eden: Colonial Water Management and Ecological Change in Kitui, Kenya 1948-63
}

\author{
James Parker
}

\section{AUTHOR'S NOTE}

This project has been generously funded by the French Institute for Research in Africa and the British Institute in Eastern Africa.

\author{
Abbreviations used in archival references \\ KNA: Kenya National Archives, Nairobi \\ BOD: Bodleian Library, Oxford University
}

1 Between the mid-1930s and independence in 1963, the British state in Kenya embarked on a wide array of water development projects in an attempt to diversify and expand the economic base of the colony, and more specifically within Non-Scheduled Areas (or native reserves). Literature on the expansion of statecraft into rural areas has predominantly focused upon anti-erosion and anti-tsetse campaigns in the fertile belt of the colony, yet all of these wider development goals necessitated the creation or management of water resources (Anderson 1993; Kjekshus 1996; Hoppe 1998). Rather than being considered by the state as essential resources for rural standards of living or as explicitly human rights, these water resources were controlled on the basis of an economic ideology that sought to erect barriers to movement, migration, and use. Prior histories of water development in Kenya have tended to prioritize large scale irrigation systems of the 1950s such as Perkerra or Mwea-Tabere, yet these schemes made up only a small number of water projects enacted during the colonial era (Chambers 1973; Anderson 2002). Using the B2 Yatta Scheme in Kitui District as a proxy for the colonial 
development project in Arid and Semi-Arid Landscapes (ASAL) more generally, this paper argues that state attempts to control access to water and grazing grounds were based on a fundamental misunderstanding of Kamba society, while also exacerbating class cleavages within local communities. On the B2, colonial shorthand for the Block 2 designation given to the Kitui portion of the Yatta in opposition to the B1 Machakos portion, water and land were only provided to those willing to pay increasing sums for the right and who would acquiesce to a range of social and cultural restrictions. Simultaneously, this article highlights how concern in Nairobi over the omnipresent threat of soil erosion in the reserves led to the enactment of Malthusian policies that pushed water sources in the reserves into disrepair (van Zwanenberg 1975). Ministry of Agriculture officials subscribed to the now debunked theory that would become known as the "tragedy of the commons," and enacted strict controls over pastoral mobility as part of their general agricultural policy (Hardin 1968; Maher 1937; Anderson \& Johnson 1989; Scoones 1995; Amutabi 2013). In the B2, water resources were managed so as to allow access to certain sectors of society while those barred from access would be forced into accepting destocking or sales measures. However, disagreements over how best to manage the B2 led to a stunted implementation while the decay of resources in the reserves led to an unprecedented build-up of pressure and need during the long drought between 1958 and 1961. I therefore argue that the unrestrained trespass from the reserves into the B2 land block in 1961 was inevitable, as state policy had left this exclusive patch of land as one of the only remaining good pasture in the region.

In arguing this from an explicitly historical standpoint, I rely on archival sources from both the British and Kenya National Archives due to difficulties in finding former residents of the colonial-era B2 Scheme. Further, due to the nature of these archival record collections this paper focuses predominantly on the B2 Grazing Scheme. However, the extension of the B1 project by Machakos officials will be outlined at specific points in order to demonstrate both alternative approaches to land management and the universality of the ecological crisis in the reserves brought about by state action. Further, the place of the B1 demonstrates that it wasn't the specific approach to land and water development in Ukambani that failed, but rather the entire premise that such developments should be contained within arbitrary borders and restricted to those with economic and social capital. By contrasting colonial water policy in the reserves with policy in the exclusive B2, the article shows how economic rather than social concerns dominated the provision of water in the region, leading to acts of rejection and desperation amongst herders in the reserves that undermined the control of land and resources set aside for richer groups. 




Base image taken from Osborne, Ethnicity and Empire, xiii.

3 Broadly speaking, the B2 Yatta Scheme sought to manage the movement and grazing of stock, with the goal of limiting land destruction and overgrazing. A stretch of volcanic rock stretching from the Tana River northwest of Kitui to the future Tsavo National Park, the Yatta plateau is marked by arid grasslands unsuited to agricultural development. Boreholes and dams pockmark the landscape, and the Yatta is bifurcated by the Mwita Syano river which eventually became the boundary between the B2 and the B1 Schemes, located today respectively in Kitui and Machakos. The area, spanning roughly 177 square miles, was closed off from the Kamba population of the district, and access to the fertile grazing and watering grounds was instead made contingent on both economic standing and a willingness to dispose of valuable stock. In both Kitui and nearby Machakos, escalating stock densities as well as poor rains created a perfect storm of ecological decay in the reserves, creating a stark dissonance between the B2 Scheme and the surrounding regions. Through the creation and restriction of water, the state (through of the Ministry of Agriculture) exacerbated demographic and socioeconomic pressures that ultimately led to the Schemes' destruction and abandonment. Their failure was driven by two interrelated assumptions: that development in pastoral regions had to be profitable (as has been demonstrated by academics such as Roger van Zwanenberg), and that better watering and grazing lands needed to be restricted to specific locations rather than the entirety of the reserves (van Zwanenberg 1975).

4 Amongst the Kamba, the presence of water was a key defining factor in settlement and stock migration in the early to mid-twentieth century. ${ }^{1}$ In areas of poor resource provision, pastoral herders were forced to migrate hundreds of miles, and those wealthy enough to do so were able to employ gangs of herders to seek out the best 
grazing lands (Ambler 1985). Such migrations, and the difficulties in working out exactly who owned the stock, caused consternation in the minds of the colonial administration throughout the mid-century, as they believed that the wholesale movement of stock led to devastating soil erosion and the destruction of grazing lands. ${ }^{2}$ Limiting this movement required the tight management of water resources, leading the Ministry of Agriculture to initiate a program of dam and borehole construction in the native reserves that they hoped would preclude the need to migrate in search of water. A network of surface water resources would save grasslands from being destroyed by migrating stock, as well as making pastoral communities easier to monitor, manage, and (most importantly) tax. While the underlying rationale for the plan appeared to be common sense, the accumulative logic of colonialism meant that water resources were not benevolently or even distributed to the community at large.

A lack of investment and planning meant that in the native reserves of Kitui District water resources were inadequate for the size of the population, and prone to frequent breakdowns. As such, the program proved unable to prevent stock movements and overgrazing, leading to a degree of fatalism amongst the Ministry of Agriculture that compelled them to adopt a more Malthusian approach to stock management in the reserves. In contrast, investment in water resources in the B2 unit were heavily capitalized and widely distributed, offering plentiful resources for the few able to access them. These resources were predicated on a strict control of access and limited usage, a policy which left its benefits to a fortunate view while failing to remedy the structural inequalities being perpetuated in the reserves. However, national economic circumstances meant that the cost-neutral program on the B2 Scheme failed to survive the 1950s, instead being replaced by a breeding and meat-production scheme driven by financial needs at the highest level. Again, while the economic rationale here is clear, the approach lacked any cultural or environmental awareness of the issues facing the reserves, leaving the B2 as a sole well-watered landscape in stark contrast to the degradation of the reserves.

6 The control of water for economic rather than humanitarian distribution is of course not limited to this particular space during this particular era, nor are the negative implications of state irrigation development. In Lesotho, British damming policy proved inadequate for the vagaries of the local climate, contributing to soil erosion and the formation of large gullies (Showers 2005). Similarly, both Meredith McKittrick and Heather Hoag have shown how colonial powers in sub-Saharan Africa sought to monetize rural riverscapes through technocratic solutions that were accepted contingently by local populations, extending William Adams' assertion that water development projects ignore the wider social and economic benefits of rivers and rains (McKittrick 2015; Hoag 2013; Adams 1992). In Kenya, these projects became increasingly prevalent in the era after 1945, as irrigation and extension projects sprouted across the colony. In Kitui however, water policy was solely concerned with limiting the movement and consumption of pastoral communities, with little care for the needs of the human or animal populations. As ecological conditions deteriorated, so were the failings of economically exclusionary water development policies that failed to equitably distribute their benefits to the tribal whole.

7 These policies, and their clear failings, were based on a misunderstanding of both society and ecology in the Kamba districts, and reflected long held preconceptions of pastoral societies in Africa more generally. Overwhelmingly, the state subscribed to 
what Herskovits termed the "cattle complex," the misguided assumption that communities' reliance on stock stemmed from the twin evils of culture and tradition (Herskowitz 1926). However, as Ian Scoones work on cattle ownership in Zimbabwe has demonstrated, communal commitment to cattle ownership resulted more from intermediary benefits such as milk production and manure (Scoones 2003). Amongst the Kamba, these benefits diluted the appeal of ranching and compulsory sales on the B2 despite the constant attention of state actors. The obsession with creating static sites of stock ownership also reflected a deep misunderstanding of the nature of Kamba society. The psychological fixation with individual if not fixed land ownership on the part of the state meshed poorly with the pastoral and semi-nomadic migration of stock within Ukambani. ${ }^{3}$ To quote John Noyes in his work on land policy in German East Africa, "debates surrounding nomadism contributed to policies of containment and confinement aimed at stabilising internal boundaries and projecting then on to the psychological constitution of disinherited natives" (Noyes 2001). Doing so necessitated closing the Yatta frontier to settlement, eliminating its ownership by the collective whole and replacing it with a strict legal framework that defined belonging and access, creating what Lynette Russell has defined as a hybrid space defined by interactive processes (Russell 2001). While stockowners at times proved willing to align themselves with these goals in order to gain access to valuable water and land in the B2, the everincreasing concentration of cattle in the reserves created a population timebomb that the state rarely proved able to resolve.

8 Their failure was not through a lack of trying, however. In Kitui especially, the Ministry of Agriculture and their local agents transitioned through a number of projects that tried to more "properly" utilise the potential of the Yatta land. However, these schemes were beset by disagreement and confusion stemming from the specific perspectives of those charged with managing them. As Jan Todd has summarized, "scientific and technical knowledge arises within a given context, through the work of people focused on particular problems, situated in particular situations or institutions, surrounded by particular kinds of peers" (Todd 1995). In the Kamba districts, the locality of science existed in a tripartite relationship between local communities, District officials, and planners in Nairobi. The divisions inherent in this relationship explains the ways that land and water management on the B2 came to be altered and manipulated over time as the national political and economic situation changed. For instance, Myles Osborne has demonstrated the degree to which development planning in Machakos (and Kitui to a lesser extent) was tied to communal loyalty during the Mau Mau rebellion, but there are a number of further issues at play here (Osborne 2012).

9 Most prevalently, central agricultural officers could not condone an initial project that offered no long-term profit, and instead pushed local officials to implement a more restrictive and explicitly economic ranching project that exacerbated ecological decline in the reserves. Further entrenching water resources behind an artificial economic boundary meant that during times of ecological stress, there were few if any outlets for herders remaining in the reserves. Historians and anthropologists such as David Anderson, Helen Tilley, Fiona Mackenzie, and Thomas Spear have all emphasized the flexible and adaptive relationship between rural populations and the lands they inhabit, yet the restrictive and rigid boundaries implemented towards the end of the 1950s in Kitui and Machakos undermined these possibilities with dire consequences (Anderson \& Johnson 1991; Anderson 1993; Tilley 2013; MacKenzie 1998; Spear 1997). ${ }^{4}$ When environmental and ecological conditions in the region degraded critically 
between 1958 and 1961, the mirage of state control over the land, water, and people evaporated as individuals and communities reasserted their control of the liminal space of the Yatta.

The opening section of this chapter situates the B2 Yatta within the social and geographic fabric of the colonial state, narrating the fluid legal status of the region as a whole. I will then show how water development in the Kitui reserves and the B2 land block escalated dramatically after 1940 and 1945 with the successive (if limited) influx of funding brought about by the Colonial Development and Welfare Act. The article then describes the implementation of the B2 (Yatta) Grazing Scheme, and the ideological basis of this. The piece then analyses how these measures led to class and economic cleavages within Kamba society and the state's inability to reckon with these changes, with a comparative analysis of the B1. Finally, the article shows how changes within the Ministry of Agriculture fomented a change within the B2 scheme, leading to divestments from reserve water supplies in order to force stock owners to sell or move their stock; such an approach demonstrates with great clarity the lack of social or cultural awareness on the part of the state.

\section{The Kitui Yatta before 1938}

None of this is to say that the state's awareness of the cattle economy arose spontaneously after the war. Indeed, they were forcefully reminded of the centrality of stock to Kamba society throughout the first part of the twentieth century, and this relationship reached a head in 1938 with a heavy handed attempt to destock the Machakos Reserve that led to the outbreak of rebellion and civil disobedience that threatened briefly to precipitate a civil war. The disagreement demonstrated the absence of cultural awareness within the colonial state as they failed to recognise the predominance of cattle, which according to Robert Tignor served as medium of exchange, used to pay dowries, penalties, and fines (Tignor 1971). More practically, the cow was a source of livelihood and independence to Kamba families, as it enabled communities to stave off incorporation into the colonial economy (Ibid.). The state's inability (or unwillingness) to countenance these social factors would become a recurring theme over the following 25 years.

12 Throughout the 1920s and 1930s, the Ministry of Agriculture became increasingly concerned at the abundance of stock within especially the Kamba reserves, and temporarily opened the Yatta land as temporary grazing in the 1920s. The distinction was key: prior to the ruling, the B2 had been Crown Lands and thus managed by the state to exclude native populations. Granting temporary grazing left the state in control of access, but gave an outlet for stockowners who had seen their stock impounded within the restricted native reserves. Within the reserves, land dwindled thanks to the creeping replacement of pastoral lands with cash crops, concentrating a growing number of stock into a shrinking landscape, and in 1934 the Land Commission argued for urgent destocking and reconditioning of the land, as well as the opening of the Yatta again for temporary grazing. By 1938, the resident soil officer claimed that at the Machakos Kamba were "rapidly drifting to a state of hopeless and miserable poverty and their land to a parching desert of rock, stones, and sand" (Maher 1937). These drastic conditions called for drastic remedies, leading the Ministry of Agriculture to call for the compulsory destocking of the Machakos Reserve; Kitui was spared at this 
time by virtue of its lower density of both stock and humans. Stock were purchased at a price below market rate, and in some cases it was claimed that over $90 \%$ of individuals' stock were sold. Unsurprisingly, the program caused an enormous amount resistance that led thousands of Kamba to march on Nairobi, as well as the formation of intersectional political parties that crossed tribal lines. As Myles Osborne describes, the threat of national rebellion forced the state's hand, and they ultimately backed down on the plan in 1939. Having made their resistance to the state clear, as well as their commitment to the pastoral economy, the Kamba returned to the rangelands having driven home the fact they wouldn't be beholden to the kinds of coercive statecraft that the destocking episode had sought to impose.

The destocking crisis precipitated a different approach to destocking in Kitui. Soon after the conclusion of the controversy, the District received a grant of $£ 10,000$ from the Colonial Development Fund for improving water supplies in the region. ${ }^{5}$ Although not wholly directed to the stock issue given the need for water in permanent settlements, the grant marks the first step into what became the overarching policy of social and agricultural development in the district. Rather than enforcing the removal of stock, the state instead began to incorporate water and environmental resources into their development plans with the goal of managing the movement and distribution of stock. Prior to this point, dam construction had been the preferred means of improving supply, a relatively informal approach that was generally undertaken by communal labour under the eye of the African District Council. While this legislative compulsion for communal labour remained in place for local supply up to 1959 it was predominantly directed to smaller scale projects the benefit the tribal whole, a means of outsourcing the cost and work of improvement onto the communities themselves. ${ }^{6}$ Such an approach absolved the state of responsibility for improving supply, and led to the continued use of existing resources rather than their extension for a growing human and stock population in the reserves. The locational marker here is important, as the state adopted dramatically divergent approaches to water provision not only between development schemes and the reserves, but also between different schemes themselves. Although the 1938 grant marks the point at which the state elected to take some responsibility for water resources in the region, provision in the reserves remained consistent for the following twenty-five years while in the exclusive spaces of the B2 large scale irrigation attempts became the preferred means of solving reconditioning and destocking.

\section{The Yatta, 1938-49}

While community-led water development took precedence within the reserves, the state dedicated their attention to creating and managing the land of the tenuously controlled Yatta. The B2 region in Kitui spanned 177 square miles of which just 50 were initially considered to be good grazing, with the rest consisting of varying degrees of bushlands and a small portion of "badlands." The Commissioner for Lands and Settlement gazette the land as a Temporary Native Land Unit on October 27th 1938, creating an outlet for pastoral communities in Kitui, as officials hoped that opening up new grazing lands would reduce overstocking in the district reserves. In return for the newly opened lands, the state charged the Local Native Commissioner a fee of 100 Shs that was to be recouped through nominal payments by stock owners. ${ }^{8}$ However a lack 
of oversight undermined the district's ability to collect the fee, and in the early years the money was rarely if ever collected. ${ }^{9}$

Indeed, demand was so high that the program was suspended in 1946 and the existing graziers removed. The land had become the preserve of a wealthy class of graziers who could afford to pay the tenancy fee; in effect, these individuals used the land as an additional grazing ground, frequently migrating their stock across the poorly marked boundary. ${ }^{10}$ Further, the group was described by the District Commissioner as being "ranchers of the most conservative type," an attribute that in his mind explained their reticence to take advantage of the good slaughter prices being offered by the Meat Marketing Board, apparently unaware of the cultural context of stock ownership. ${ }^{11}$ Such migrations caused major harm to the grasslands and watering points along the way, furthering the very ecological damage that the plan had sought to alleviate. The state's exhibition of soft power had thus come undone due to class and economic dynamics that they hadn't fully prepared for; an oversight that would reoccur again over the next few years. One official even claimed that Kamba held what amounted to a religious attitude towards their cattle, while another appeared certain that any attempts to compulsorily destock to the necessary degree would prove futile. ${ }^{12}$ Despite the setback, by 1948 the recovery of the grasslands had proceeded quickly enough that stock were slowly able to be readmitted. Rather than charging a grazing fee, the state instead opted for a quid pro quo arrangement that allowed stockowners to access the land if they agreed to clear two acres of heavy bush per 30 head of cattle, a move designed to increase the amount of good grazing pasture in the region. ${ }^{13}$ Owners from the five surrounding locations began moving their stock into the B2 the following year.

The roughshod implementation of the temporary grazing scheme led the state to take a more hands on approach to improving grazing conditions in the land, as population increases meant that the region was quickly becoming the last hope for grazing control and development in the region. Through the provision of better water supplies it was hoped that the carrying capacity of the land could be gradually increased, allowing a greater number of stock owners to enter the area under strict grazing conditions. Indeed, water was intricately tied to the state's idealized vision of land use, and from the very inception of the B2 Scheme in 1949 access would be conditional on the acceptance of any conditions the state sought to impose, "however rigid." ${ }^{14}$ Such impositions were deemed necessary for three, interrelated reasons, all of which relied upon the compulsion of Kamba stockowners. First, restrictions would allow the B2 to most efficiently act as a relief area for the overstocked reserves. Second, the enforcement of good management in the Yatta would demonstrate the benefits of improved animal husbandry to Kamba in other parts of the reserve. Finally, the improved quality of stock grazing in the scheme would offer a large supply of slaughter stock for export to other districts. Taken collectively, these intentions indicate the state's desire for more efficient and more profitable stock ownership, stripping it of any social or cultural significance in favour of economic utility.

As the destocking controversy of 1938 had demonstrated, however, the state lacked any real political means for compelling stock owners to take part in this scheme. Despite degrees of land degradation within the reserves and the growing threat of overstocking, Kamba stockowners had little interest in submitting to state directives unless absolutely necessary. Owners of smaller herds lacked the labour to send their stock to the B2 to take advantage of the land clearance agreement, while larger herders 
had enough social capital and political leverage to come and go as they pleased. As such, the state elected to weaponize the one factor that they could control in compelling owners to use the new scheme. Creating new water resources could compel stock owners to acquiesce to restrictions in return for access, a move that would solve overstocking the reserves through the osmosis of larger herds into the new lands.

\section{The B2 (Yatta) Grazing Scheme} the impact of long range migration, but all but one of these provided little value. ${ }^{15}$ Alongside the logistical challenges of creating accessible resources, there was also the very practical issue of whether the land and ecology could provide such production. Even by the end of the 1940s, as plans to turn the B2 into a self-sufficient grazing scheme were being crystallized, there was still confusion within the Ministry of Agriculture and the District Commission about whether the requisite resources were available. In addition to the existing dams, the early provision of basic boreholes was soon deemed essential to the scheme, necessitating widespread surveys to discover the depth of the bore, transport distances, and the resistivity of the land. ${ }^{16}$ While Kitui District Commissioner W. F. P. Kelly retained confidence in the potential of dam building in the area, despite the failure of the eleven prior attempts, he conceded that the creation of a borehole network would be "essential for an economic ranching scheme." ${ }^{17}$ To that end, the initial estimates for the project called for five boreholes of no more than 400 feet to be drilled, at a cost of 18,000 Shs each. ${ }^{18}$ At this point no geophysical surveys had been conducted in the region, and it wasn't until June of 1950 (three months after the initial estimates had been submitted and approved) that a report on borehole investigations in the area was produced.

Surveyors carried out tests in nine different areas within the Yatta, chosen primarily for their geographic distribution rather than any specific geological criteria. Such an approach was driven by a very practical necessity, to achieve "a wide and even distribution of supplies, in order that efficient grazing control in the future could be ensured." 19 Four of the sites were recommended for drilling, and the surveyors noted that progress on the project would be both difficult and slow due to the hardness of the rock. However, Engineer-Geologist G. E. Classen also warned that boreholes were just one aspect of the solution as any concentration of stock around the chosen locations would simply lead to the perpetuation of overgrazing. Instead, they advised that boreholes "should rather be regarded as reserves of water in times of drought when dams, sited at more or less regular intervals and providing the normal source of supply for cattle, become dry." ${ }^{20}$ All involved in the project thus agreed on the need for equitably distributed supplies, but it remained unclear throughout the course of the scheme about whether these would ever come to fruition. Without remedy, the incomplete nature of the water network in the B2 threatened to exacerbate overgrazing and social tensions across the reserve by limiting the practical utility of the project.

The poor planning and the uncertainty surrounding available resources meant that the viability of the scheme always remained in question, even after its confirmation in 1952. As more stock arrived, it became increasingly clear that the available resources there were insufficient for the purpose, while the dams and boreholes of the 
surrounding reserves were starved of investment as financing channelled into the Yatta. However, the scale of this investment never allowed for the expansion of borehole resources in the $\mathrm{B} 2$, and instead small grants were provided for the building of small concrete dams in 1954 and 1955. Of the $£ 20,000$ allocated to water resources in the scheme by 1960, half of this was allocated to borehole drilling in 1952 in the form of a loan from the African Land and Development Board. ${ }^{21}$ The rest contributed to the construction of dams that as recently as 1950 had been claimed to be inappropriate for the task at hand.

21 The change in policy stemmed primarily from the geological qualities of the region. By 1954 only three of the five boreholes were in use, and surveyors realized that the rocky base of southern portion of the Yatta was utterly impenetrable. As such, surface and subsurface dams were the only possible solution if this portion of the land was to be properly utilized. ${ }^{22}$ These would be supplemented by the largest infrastructural element of the B2 Scheme, the Yatta Furrow. To reduce the overreliance on increasingly unreliable dams and boreholes, the African Land Utilization and Development Board proposed the construction of a canal from the Thika River to the Mwita Syano that bifurcated the Yatta. The project was to be undertaken by Mau Mau detainees swept up in Operation Anvil in 1954, as the state and Prisons Office sought productive employment for suspected rebels. In addition to the Furrow, the districts of Kitui and Machakos received a disproportionate per capita amount of colonial development funding throughout the Emergency, part of what Osborne has termed the "development deal" designed to buy Kamba loyalty (Osborne 2015). Much like irrigation works in Tana River and elsewhere, the Yatta Furrow took advantage of the political situation to fulfil long term policy objectives; a canal had been proposed as early as 1938 but had not come to fruition due to a lack of labour and money. The Emergency remedied both of these concerns, enabling the construction of a ten-feet wide, forty-mile-long canal that provided irrigated agricultural plots as well as rotational grazing for pastoral communities. After detainees began to be repatriated in 1958 , the final parts of the project were completed by paid labourers. Costing $£ 350,000$, by the time of its completion in 1959 it was hoped that the Furrow would provide grazing for 20,000 cattle, a marked increase on the 7,500 present there in $1959 . .^{23}$ The increased stock numbers would require further extensions of the water supply into the B2 area through added pipelines and the full clearance of the southern bush, but by 1960 social and environmental conditions had begun to conspire against the fulfilment of these hopes.

\section{The B1 Yatta 1938-58}

Simultaneously, across the district border in Machakos, the District office there chose a different avenue to the exploitation of the Yatta's potential. Machakos district had long been considered one of the most densely populated regions in the colony, and as such received the highest per capita development spending of any location (Osborne 2015). For the most part, spending was directed at the spectre of soil erosion, as well the omnipresent threat of tsetse fly. ${ }^{24}$ The state deemed these twin evils the major barriers to production, and necessitated strict controls of grazing and stock growth to prevent what they considered the denudation of the landscape. Within the native reserves, the African Land Utilisation and Settlement Board in 1947 believed that the carrying 
capacity of the land was exceeded by nearly 190,000 people, with few outlets for either settlement or economic growth. ${ }^{25}$ Despite allocating over $£ 100,000$ to betterment in the reserves between 1952 and 1953, escalating population densities within Machakos made the Machakos Yatta, named the B1, an area which was added to the densely settled area of Machakos an increasingly precious resource. ${ }^{26}$

The B1 located in Machakos had been gazetted as a Temporary Native Land Unit in 1938 to allow for dry season grazing and lay on the Yatta Plateau between the Athi and the Mwita Syano rivers. The B1 had first been administratively assigned to the Kamba under the Kenya Land Commission of 1933, on the condition that the state had the right to reincorporate the area into the Crown Lands in the event of what they considered be misuse. ${ }^{27}$ To this end, the African District Council of Machakos took on the running of the area, charging six shilling per head of cattle per annum. ${ }^{28}$ Some $5,000 \mathrm{Kamba}$ resided temporarily in the area along with around 23,000 stock animals, revealing a somewhat different approach to land management than was occurring on the B2, where even temporary settlement was outlawed. ${ }^{29}$ Rather than evicting squatting herders in the B1, as had happened in the B2, the Machakos District Council opted to allow relatively high levels of settlement in the region to try and ease the burden of overcrowding in the reserves. By 1953 the B1 had reached its capacity and exhibited signs of increasing overgrazing thanks to the relatively unencumbered arrival of new stock. With no new admittances possible after 1953, the region was unable to offer any respite for the reserve lands in Machakos, necessitating greater legal and infrastructural interventions into the landscape to solve the question of grazing in the district..$^{30}$ As District Commissioner for Machackos D.J. Penwill asserted, "the African reserves are bursting with stock, and somehow or other an outlet must be found or the situation will be tragic." 31

To try and solve the issue, the Machakos District Office began to implement plans for a full settlement and ranching scheme that would allow accepted graziers live and work in the B1. These residents would live on separated plots, and graze their cattle on a rotational basis in demarcated paddocks. The viability of this scheme was enabled first by the construction of 31 dams and 8 boreholes and then the construction of the Furrow itself in 1958. ${ }^{32}$ These related developments allowed the District Agricultural Committee and the Machakos ADC to exert much stronger controls over the B1, reducing the number of stock allowed while also centralizing their movements throughout the 1950s. Nonetheless, access to this region was dictated by economic standing, and so the B1 Ranch did little to overcome structural inequalities within the Machakos communities, or the ecological damage to the reserves created by colonial administrative policies. Generally speaking however, although the initial methods differed, the overt goal in the Machakos B1 of creating exclusionary water and grazing areas replicated control measures in the B2.

\section{Enclosing Water Resources in the B2}

Throughout the lifetime of the project, conditions in the B2 area to a great extent relied upon the state of the reserves. Even prior to the Scheme's genesis, the land there had been essential emergency grazing lands for the Kamba in Kitui and Machakos. Delineating the area as a self-sufficient scheme not only required the creation and management of water infrastructure, but also the closing of this liminal space to 
unwelcome subjects. That water resources in the reserve were inadequate was no secret to the District Officers charged with overseeing the region, and in the barren year of 1944 the outgoing DC went as far to say that "the tribe at present depends for its existence on "illegal" grazing outside of the gazetted reserve boundaries." ${ }^{33}$ The community impact of hardening locational boundaries was of secondary importance to the control of grazing lands and the demonstration of effective land use, however.

The enclosure of the Kitui Yatta was brought about by twin fears. On the other, the delicate ecological balance of the area continued to be threatened by illegal grazing from Kitui as well, requiring strict access regulations to be imposed in order to protect the grasslands and the few water supplies. Frequent incursions from both areas throughout the early 1940s draw attention to the liminal and unmanaged nature of the land; although now well established as temporary native land, few mechanisms were in place to ensure that graziers abided by the rules. It wasn't until 1945 that the District Office finally demarcated the easterly boundary of the area in an attempt to assert their control over the region, leaving "no possible excuse for trespassers" from either Machakos or the Kitui reserve..$^{34}$ Restricting access was the first step in abolishing settlement in the area, instead enforcing "the idea of a European owned stock farm for the production of beef" by ensuring the land was directed purely to the extension of grazing. ${ }^{35}$ From this point onwards, access from Kitui became increasingly restricted in order to maximize both the quality of the land and the financial potential of the scheme.

Understandably, restricting access to valuable emergency lands caused consternation amongst Kamba stockowners who saw the B2 as a necessary tool for limiting stock losses during times of drought or famine. The problem was especially exacerbated in the formative years of grazing policy after the war, in advance of the centralized scheme's initiation. Rather than opening the area to graziers from the six locations surrounding the Yatta, access was granted to only one location at a time, with the rationale that each location's stock could be grazed their while their home location recovered. ${ }^{36}$ In response, Councillors Mwenda and Kasina of the Mutonguni and Mwigani locations suggested that each of the six locations be allowed to graze 1,000 head of stock on the land. ${ }^{37}$ The disagreement reveals a key division in perceptions of the B2. While the President of the Local Native Council, R.D.F. Ryland, believed the land to be an outlet for the temporary respite of reserve grasslands, both Chiefs and Kamba stockowners envisioned it as a pressure valve for grazing. At a basic level, the state viewed grazing on the Yatta and in the reserves as mutually exclusive solutions while the Kamba firmly believed it to be an extension of the reserve lands.

Exclusionary access arrangements were gradually codified after 1948, as the District's Local Native Council agreed to an array of regulations in June. Branding in particular was a key element of the state's attempt to transition the Yatta away from a communal outlet towards a manageable, bureaucratized space. As part of these attempts, a cattle census took place in 1949 that necessitated the branding of all stock in the district, as without this it "would be impossible to introduce good cattle farming" through the management of pasture and the provision of water supplies. ${ }^{38}$ Again, while the process was part of the systematic management of land engrained during the latter part of the colonial era it erected another barrier for communal use of the land, in essence creating a legally binding sense of who could or could not access superior grazing and watering points. After surveying the Yatta alongside the Senior Assistant Agricultural 
Officer, the President of the Council proposed opening the land to grazing as long as stock numbers could be regulated. Those stock could only be grazed on the land if they came from selected manyattas surrounding the area and if they were branded, while stockowners from other locations were barred from migrating their stock to the Mwita Syano on the western edge of the Yatta. ${ }^{39}$ In effect, this gave access to the privileged few while stock owners who refused to have their cattle regulated were barred from one of the major watering grounds in the region.

These prerequisites were essential for the finalization of the B2 Rules in 1952, which enshrined access regulations within a legal framework. It was hoped that the Scheme would depopulate the reserve lands and thus improve the grazing situation there, however a number of regulations worked against this desire. The Rules issued licenses to stock owners who wished to graze their land on the unit and gave the District Commissioner the power to exclude or expel surplus stock in the event that owners tried to circumvent the regulations. Further, stock could only be removed from the B2 with the express permission of the Commissioner. ${ }^{40}$ This legislation hoped to enforce stock sales by making it difficult to migrate stock back and forth across the border, thus creating a terminal density within the reserves. In actuality, those unable to afford the charge claimed that their exclusion from the project enabled wealthier owners to distribute their stock across a larger landscape. Restrictive legislation meant that many stockowners used the B2 as a place where older stock could be put out to pasture, rather than improving the quality of younger animals as the state had intended. By 1955,144 owners ( $25.6 \%$ of the total) accounted for over $62 \%$ of the stock on the Yatta:

\begin{tabular}{|l|l|l|}
\hline Cattle Numbers & No. of Owners & Total Stock \\
\hline$>100$ & 2 & 269 \\
\hline Between 50 and 100 & 22 & 1467 \\
\hline Between 30 and 50 & 45 & 1651 \\
\hline Between 20 and 30 & 80 & 1839 \\
\hline Between 10 and 20 & 158 & 2007 \\
\hline$<10$ & 254 & 1159 \\
\hline Total & 561 & 8392 \\
\hline
\end{tabular}

BV/14/244. Kitui (B.2) Yatta Grazing Scheme, 1955, 2

The above table demonstrates that definitions of wealth varied wildly between the Kamba and the colonial state, as administrators claimed that the data disproved Kamba complaints about richer owners' monopoly of the region by proving that the area was open to any size of herd. Technically speaking, this assertion is correct, as the table shows that the most populous ownership stratum was that of owners with herds smaller than 10 stock. In terms of total cattle however table one makes abundantly clear the fact smallholders, while individually numerous, had their stock outnumbered by those possessing more than 20 cattle at a time. This disparity gets to the heart of why the state disregarded Kamba complaints regarding the scheme, as their definitions of large- and smallholders differed greatly from complainants. For those complainants, the very perception that the B2 was an exclusive space for richer members of the 
community fed into the belief that resources were being redirected away from the tribe and region at large. From the perspective of these families, water and land were available only to those with social and financial capital. Given the periodic drought and famines suffered in the Native Reserves, the withholding of grazing and water behind an artificial boundary in times of suffering seemed to constitute a betrayal of communal principles by the state. Poorer stock owners were therefore left with no choice but to either toil on degraded lands or to trespass into crown lands.

\section{Transitioning to a B2 Ranching Scheme, 1956}

31 Despite these pressures, within the scheme's boundaries the state had succeeded in creating what one official called a "veritable Garden of Eden," characterized by improved pastures and well-watered stock. Further, the project proved to be enormously economical for the African District Council, as the initial capital injection and increased grazing fee fostered a self-sufficient development scheme. Beneath the surface however, confusion over the project's goals within the Ministry of Agriculture and the state's need for increased profitability in the area contributed to a decline on the B2 that critically endangered its viability. In particular, conflicts over the ultimate aims of the project were driven by central experts in the Ministry of Agriculture, who frequently clashed with local officials over the point and economic utility of the B2 project. This latter point is highly indicative of rural development more general under the late-colonial state, as economically driven central officials clashed with "men on the spot" over the social and political consequences of development schemes.

Despite periodic advancements in land management within the District at large the Provincial Agricultural officer still feared that livestock management stood on tenuous ground in the region. Although "more enlightened people are realizing that stock need to be controlled," he feared that for the majority this was a "nettle which is still not being boldly grasped." ${ }^{41}$ To counter these concerns, the Livestock Officer recommended an increase in funding on the Yatta to pay for improved water and grazing facilities, as part of a desire to drive home the benefits of efficient land management to both locals and the colonial state at large, while also expanding the potential benefits of the project for the surrounding reserves. He advised the project become "a demonstration of what can be done when reasonable capital be provided" by tapping into existing resources..$^{42}$ The exhibitory imperative implied here caused confusion, especially between Ministry of Agriculture officials and the men on the spot. Local officials believed that the improved grazing on the Yatta could demonstrate the benefits of development investment in arid regions by easing pressures in the reserves, but this sentiment was not widely shared in Nairobi. In contrast, one official argued that the scheme's "primary purpose is to demonstrate that marginal lands can be farmed successfully by proper controlled grazing," and that any claims that the project was designed to relieve grazing pressures in the reserves was "entirely erroneous" and that this outcome was "a fortuitous benefit." ${ }^{33}$ of course, this claim is easily dismissed if we consider the long-term discussions surrounding the scheme's launch.

33 The obstinacy with which the point was made incensed livestock and agriculture officials within the B2, and understandably so. Approval for the project in 1952 had specifically outlined grazing relief as a cornerstone of the scheme's importance, with the demonstration of good land use being of secondary importance. To this point, the 
B2 had shown that restricted grazing could improve land quality and water points in both the reserves and the scheme itself, even considering the disparity in investment between the two locations. Indeed, such was their belief in the project's utility that the African District Council increased grazing fees to ten shillings per animal in $1956 .{ }^{44} \mathrm{The}$ money allowed the African District Council and District Office to extend water supplies in the southern portion of the Yatta, extending the carrying capacity of the land and allowing more stock to be taken off from nearby locations. ${ }^{45}$ Nonetheless, perceptions grew that the benefits offered by the scheme had reached their nadir, and that in the long term it would be near impossible to increase the stock population any further. Despite the protestations of local officials, changes in governmental priorities stemming from financial pressures as well as the heightened tensions of the Emergency generated a range of counter policies to improve the usefulness of the project. As early as 1955, officials within the Agricultural and Veterinary Offices tentatively began to suggest a reorientation of the scheme with the intention of making the area more profitable for the regional economy. The abundance of animals across Ukambani led profit-minded administrators to see the region as a reservoir of slaughter stock to feed the increasing urban population of the colony. A generally broad consensus developed amongst all departments that the B2 had a role to play in this, yet opinions diverged about the best way to accomplish it. The chief Livestock Officer on the scheme, E. Hall, felt the best way to do this was to prove the benefits of limited stock ownership to the greater herd through the expansion of the existing watering and grazing scheme. ${ }^{46}$ By proving that the quality of stock could be improved by reducing herds and taking advantage of newly invested water resources, owners would be incentivized to sell stock and use the money to improve the land in neighbouring locations. His plan to encourage this proposal compelled stock owners in the Yatta to sell the "natural increase" in their herds for slaughter, but the area generally lacked the infrastructural nodes to expand sales further. ${ }^{47}$ The first steps to remedy this came with the construction of a sale site on the edge of the Yatta, designed to impound cattle before sale to prevent them from overgrazing the Scheme in the intervening period. ${ }^{48} \mathrm{It}$ became increasingly clear, however, that the quality of stock leaving both the Yatta and the surrounding locations would not satiate regional demands thanks to the reticence of the local community to sell their best stock. Evidently, if anything was to become of the Ministry's hopes for a robust meat sales market then it would have to occur through compulsion rather than volunteerism.

These difficulties further served to drive home the sentiment amongst officials that the scheme was "past its sell by date," in the words of the Assistant Agricultural Officer. ${ }^{49}$ They remarked that the project no longer contributed anything to the problem of overgrazing in the Reserve, as stockowners loudly and forcefully rejected destocking measures, and recommended a gradual transition to ranching. Under the nascent ranching plan, any stock already on the B2 would be allowed to remain but none would be admitted on the old terms; further, any stock leaving during the intermediary period would be prevented from returning. Young stock were then to be bought from owners in the reserves, in order to be fed, fattened, and sold to the Meat Board. ${ }^{50}$ The projected changes ostensibly served two purposes. First, it would prevent the Yatta from becoming an incubator for older, unprofitable stock, as had been the case for much of the scheme's existence. Second, it would provide valuable funds to the African 
District Council that could then be reinvested in the community, as the higher price of good quality meat would hopefully lead to increased sales to the Meat Board.

There was, however, a dark underbelly to these changes. With young stock being earmarked for the B2, the population of the reserves would be built of predominantly older and less valuable cattle. In the eyes of the Agricultural Committee, their lack of value essentially made these animals a disposable drain on resources, utterly ignoring their social and economic value to Kamba communities. As the stock population grew past the state's recommended carrying capacity for the land, the Asst. Agricultural officer recommended drastic measures in dealing with the issue that included withholding water resources if owners refused to sell or slaughter their animals. He argued that the overgrazing problem was fundamentally driven by access to resources, and that it would be better to suppress the availability of water and see stock die than extend water supplies and perpetuate overgrazing. ${ }^{51}$ The recommendation replicated the official sentiments of the Royal Commission on land management, and was justified by the concern that providing water in well stocked areas would contribute to an increase in poor scrub stock. ${ }^{52}$ However, the Malthusian sentiments at the heart of the policy suggestion get to the heart of the cultural dissonance between the state and owners. For the state, stock numbers were an environmental and ecological hazard that needed to be controlled by any means necessary. For owners, stock were a social and economic necessity that were to be sustained at all costs. It is especially critical to note that the Ministry was by no means unaware of the fallacies of their destocking approach. The 1938 incident had left a lasting imprint on institutional knowledge, and just ten years earlier the then-DC of Machakos, G.R.B Brown, had fully asserted the fallacy of mass destocking as a policy destined for violent rejection..$^{53}$ Even thenGovernor Sir Philip Mitchell appeared aware of the importance of stock to the community in 1944 when suggesting that new grazing lands be sought out instead of limiting population growth, given the needs of the people for essential meat, milk, and manure ${ }^{54}$ That they and others had had their common-sense rejected and discarded is symptomatic of the Ministry's drive for progress at any cost after 1955.

\section{Ranching Concerns, 1956-61}

The B2's transition from grazing scheme to ranching occurred quickly over the course of 1956 and 1957. Initial estimates placed the total capital expenditure on the Ranch at $£ 62,700$, the vast majority of which would be used to purchase the existing calves residing there as well as siting new water supplies. ${ }^{55}$ The Agricultural office hoped that by the third year the Ranch would be selling 1,000 stock per year to the Meat Board, as well as purchasing 1,000 new calves a year..$^{56}$ The circulation of stock would initially contribute to the gradual sale of all existing tenant stock, and their replacement with new, younger animals that could be improved for sale. The circulation of stock this enabled would gradually lead to the migration of young animals to the Ranch, leaving stockowners in the reserve to graze only mature older animals. Ideally, the Agricultural Office hoped that the removal of fresh stock would lead to the natural decline of stock numbers in the Reserves as breeding stock aged, capping the possible increase. Of course, managing the circle of life in this way relied upon the African District Council being able to fund the purchase of young stock, and the willingness of owners in the 
reserves to sell. The disparity between theory and reality would again prove telling as the Ranch progressed. itself. Little time was given over to the impact of this Pyrrhic victory on local stockholders, and instead water was deemed to be a sacrificial entity that could be leveraged to secure the wider aims of the agriculture department. Ranching in alliance with water restrictions could artificially suppress natural increases by removing valuable young animals for fattening and sale outside of the region, while starving out older or less economically useful stock. By mid 1955, there were nearly five hundred thousand units of stock in the Native Land Unit, a number that the state considered to be an unsustainable level of overgrazing. However, their responses were consistently opposed by the District Commissioner and his subordinates who saw ranching and grazing control as retrogressive steps imposed from above, without any consideration of local social and cultural needs. The disagreement here is telling, and again sets out the fundamental fracture within development policy. Rather than paying heed to the individuals on the ground, the Agricultural office felt that destocking was a problem only solved through a wholescale importation of European or American ranching models and restrictive legislation, considering the stock question a social problem rather than one bearing any relation to the economics of agriculture. ${ }^{58}$

So it was that water became the key point of leverage within Kitui's development policy. In Kitui, stock and water restrictions ensured that vast areas were starved of resources and ecologically tenuous, while similar restrictions had been imposed across the border in Kitui. Broken or closed water points would lead to desperation on the part of stockowners, and desperation would lead to sale. ${ }^{59}$ The policy left the nascent ranching scheme on the B2 as the only well-watered and low density grazing in the area; the final plans dictated that $90 \%$ of the admitted cattle should be castrated young steers, while $10 \%$ should be young heifers that would breed with high quality imported bulls, all under the watchful eye of the Kitui Development Committee rather than the ADC..$^{60}$ "The improved progeny" could then be sold back to the reserve to as a manifestation of the benefits of good grazing and breeding, providing an incentive for external stockholders to clear bush for paddocks. More importantly, the nucleus of high-quality stock could be sold across the colony and provide a much-needed cash injection for the District Council. The economic potential of the project ensured that it was warmly welcomed by the District Agricultural Committee, and they committed to the importation of ten Sahiwal bulls from the Veterinary Breeding Centre in Ngong. ${ }^{61}$ These bulls, alongside legislative compulsion and greater incentives for stockowners, allowed the project to expand rapidly. In the four years between 1956 and 1960, 2770 head of cattle were sold for a total of $£ 21,138$, while a herd of 1,000 young steers had settled in the area. Young heifers imported for breeding were kept for a period of around fifteen months before being returned to their owners in the reserve "with a calf at foot and in-calf a second time," and by 1960 there were 277 females present in the area..$^{62}$ In a vacuum, the uptake of the ranching and destocking project here proved 
successful, as young male stock migrated to the area to be fattened and sold while the quality of calves was improved through targeted breeding campaigns.

However, flaws soon became evident in the theoretical foundations of the project. Compelling individuals to migrate their young stock into the B2 for breeding and sale could only lessen pressure in the reserves if the stock population there remained static or fell thanks to Malthusian checks. Indeed, the very point of limiting water access in the reserves was to enforce an artificial cap on stock ownership, believing that owners would be left with no other choice but to either migrate their young stock and then dispose of older stock through either sale or death. However, the conflict between state enforced sale or redistribution and local reticence to comply initially led to few problems in the years between 1956 and 1960, thanks to abundant rainfall in the reserves. Those who saw the benefit of stock improvement or sales did so, as evidenced by the dramatic increase in steers within the $\mathrm{B} 2$ that were drawn by the abundance of good grazing lands. Those unable to afford the fees, or simply unwilling to migrate their stock, continued to do so thanks to the copiousness of watering points and the richness of grazing lands within the reserves. The ecological balance here drew the state into a false sense of security, blinding them to the concerning increase in the stock population of the reserves.

By 1960 however this favourable state of affairs was coming to a close as the population of stock in Kitui as a whole began to increase tremendously, and the ADC feared that the grasslands would no longer be able to hold the population. Without stock limitation legislation in the reserves, as opposed to environmental controls, destocking would be impossible..$^{63}$ The impending ecological crisis was further exacerbated by the decision of the African District Council in 1958 to remove dam construction and maintenance from communal labour regulations, removing any local compulsion to fix broken dams or boreholes. ${ }^{64}$ The motivations for this were two fold, in that it represented a form of resistance towards state-led compulsion, while also implying that water development should be part of the full state development program in the reserves. However, local officials proved unwilling and unable to meet the labour or funding shortfall for the dams due to a shortage of machinery that left many locations suffering from severe shortages. As these resources dwindled, so the abundance of water in the B2 appeared more egregious by the month. Outside of the district, similar pressures were building across the border in Machakos, as unrestrained grazing left much of the district barren. In the B1 Yatta, across the Mwita Syano from the B2, the Machakos Development Committee had proposed an implemented a settlement scheme that placed static plots around a network of boreholes and the river itself; again, access to better land and watering was restricted to those willing to pay for it. The coalescence of factors in all of the surrounding locations left the B2 as one of the few, if not the only, areas of abundant grazing pastures in the entire region.

The tenuous barriers of the project began to crumble throughout the long, dry summer of 1960. The year stood as the third successive year of bad rains yet, much to the state's chagrin, "the Kitui livestock surprised all but its owners by its ability to survive almost total starvation," a phenomenon that dealt a blow to the state's hopes that famine would "act as a Malthusian check on the District's excessive cattle population." ${ }^{65}$ Indeed, stock sales remained a last resort for owners within the reserve who preferred to dispose of goats, chickens, and honey before their cattle, and despite the paucity of resources the year saw a net increase in numbers within the reserve. Escalating 
population densities in the reserves led the African District Council to increase their calls for settlement to be allowed in the B2. They considered the fee structure and migration rights to be "onerous and unnecessary," and that better use could be made of the area if it was settled by stockholders from the reserves. ${ }^{66}$ By this stage, the estimated cattle population of the District as a whole was 274,000 , some 64,000 greater than the suggested carrying capacity of the land. ${ }^{67}$ Stockowners had begun to refuse compulsory sale and slaughter, and fees continued to restrict the number of individuals who could migrate young stock into B2. Accordingly, trespass into the area became increasingly common that summer from both Kitui and Machakos. ${ }^{68}$ For all intents and purposes, the reserves had become a pressure cooker, the land bursting at the seams as available grasslands dwindled and with few outlets available. The B2's very existence as an Edenic grazing, watering, and breeding ground rested precariously on the reserves' continued ability to withstand population growth, a phenomenon that in itself relied upon rain and water resources. Those keystones would not last.

\section{The B1 Yatta, 1952-61} the B1. Long seen as the lesser of the two schemes, both in terms of its potential and its administrative importance, overgrazing had pushed the area to its ecological limit. The B1 Ranching Scheme had from 1952 been made up of 14 settlement areas each consisting of between ten and fourteen farms. Stock ownership had been limited to just fourteen cattle per farm, and each settlement lay within one mile of a water supply. ${ }^{69}$ However, the only permanent supply before 1958 was the Athi River, which lay on average nine miles from each settlement. Evidently, the lack of permanent, year-round supplies acted as a further cap on stock ownership, as the availability of the resource only provided enough to water calves and a maximum of three working stock. These ecological limits, as well as other internal pressures, meant that management of grazing and migration proved difficult.

By 1957, it was clear to the District Agricultural office that the area was suffering from a number of linked issues, stemming primarily from a lack of legal oversight. Most importantly, a lack of continuity in overseeing officers had led to both an abundance of absentee owners, making the proper disposal of stock impossible, and the encroachment of bush due to illegal overstocking and the breakdown of rotational grazing that had occurred due to a lack of watering points. ${ }^{70}$ These issues appeared especially stark within comparisons to the B2 area in Kitui, which was deemed to be much more satisfactorily run than the Machakos side of the boundary. ${ }^{71}$ The dichotomy between the Edenic lands of the Kitui Yatta and the barren and overstocked B1 would prove to have long lasting consequences, and pushed the Machakos Agricultural Committee to plan remedial work to save the landscape. To solve these issues, the District Agricultural Committee proposed a policy of permanent settlement over an area of 133,000 acres, centred around five paddocks with a "suitable" number of settlers chosen from graziers lacking any substantial landholding in the Machakos reserve. ${ }^{72}$ These settlers would be allowed to graze twelve head of cattle under the system beginning in 1957, one paddock would be removed from grazing each year to allow for a regeneration period lasting over two years. ${ }^{73}$ It was not lost on the committee that in the earliest years of the transition an enormous amount of land 
would be removed from circulation. However, the deleterious effect this had on stock owners was deemed unavoidable if the land on the Yatta was to be rescued from encroaching bushlands, poor soils, and patchy grazing. ${ }^{74}$

Initially, the project reduced the number of cattle on the scheme from 7,000 to just 5,000 , a figure still below the fifty percent reduction anticipated by the committee. Nonetheless, the project served to flood the reserve with non-renewed stock while elevating the quality and services of the B1. Although popular with those chosen to reside on the scheme, the giving over of precious water resources to a few fortunate settlers caused consternation amongst the majority of graziers in the reserve. Further, the tightening of administrative control over the region led to compulsory branding and tagging as well as the outlawing of stock migration into the area. Such barriers appeared abruptly in the eyes of Kamba in the reserves, especially those absentee owners who saw their large herds banished from the region. With little good grazing in the reserves and restrictions on the movement of their stock, the project actually exacerbated land issues within the reserves that contributed to a slow build up in population pressure. Having taken a laissez faire approach to the B1 in the past, the settlement and grazing scheme tried too much too quickly. It is then unsurprising that hostility became increasingly evident throughout 1958 and beyond, as conditions in the reserve declined. Communal labour in the $\mathrm{B} 1$ declined alongside access restrictions, while absentee owners refused to remove their stock from the region. ${ }^{75}$ The District office had long blamed the condition of the Machakos Yatta on the "uncooperative, backwards, and selfish attitude" of stockowners, yet in actuality their responses reflected a long term history of land use in the area that was being abruptly halted to help manage land pressures that were of the state's own making. ${ }^{76}$

By 1959, some of these pressures were becoming increasingly acute even within the paddock project. Poor rains that year meant that many of the dams stood dry, and left the Athi and Mwita Syano rivers as the only viable watering grounds. ${ }^{77}$ Although grazing remained passable at this stage, Paddock E on the southwestern edge of the B1 was beginning to exhibit a decay in grazing quality that was exceeded only by those of the reserves themselves. As the year wore on, these conditions spread to C and D Paddocks, which began to exhibit signs of overgrazing. These conditions forced the veterinary department to reduce the number of stock per acre, further ejecting animals back into the already overcrowded reserves. By this stage, the number of stock units on the plateau stood at over seven thousand, well over the recommended limit. ${ }^{78}$ The necessity of stock reduction pushed the Veterinary office to propose destocking via either legislative reform or direct action, neither of which would prove popular with the increasing number of settlers seeking any and all adequate grounds for their animals. ${ }^{79}$ By May of the following year, D and E paddocks constituted a "continual problem of overgrazing, trespassing, and erosion" due to the continued lack of rain. The presence of the Furrow mitigated these issues to a certain degree, and grazing remained good on Paddocks A, B, and C thanks to better rains, but on the whole conditions on the Plateau and in the reserves deteriorated rapidly due to the prevailing environmental conditions.

This deterioration reveals the fallacy at the heart of the B1 Scheme. Unlike the B2, officers in Machakos first had to reign in what they saw as malignant land use, before reinstating their preferred policy. The introduction of the paddock project reduced available lands that had been grazed for generations and made essential water 
resources available only to a lucky few. However, the prevailing conditions of the reserves meant that grazing and population pressures across the entire district were terminal in nature, and simply ejecting non-paying or absentee stockowners created an overabundance of animals within the reserve that exacerbated ecological pressures there. As conditions deteriorated during the long droughts beginning in 1959, owners' appetite for greener pastures and essential water resources contributed to a build-up in pressure that pushed up against the very boundaries of the district. Making access contingent on social and economic control left an enormous underclass of owners unwilling or unable to dispose of their stock, and desperate for any outlet for their deteriorating stock.

\section{The Fall of State Development on the B2 Yatta, 1961 Onwards} and manifest. Collectively, they amounted to a dependence on three interrelated conditions: Kamba willingness to dispose of their stock, the control and leverage of limited water resources, and the ability to manage stock movement. Having failed in the first case, the remaining tenets collapsed during a period of previously unprecedented climate conditions.

Despite drought being manifest in the surrounding reserves and districts after the summer of 1958, the B2 had remained plentifully watered thanks to the arrival of the Yatta Furrow that year, depositing ten cubic feet per second into the Mwita Syano river. However, the new resources were available only to those within the B2 or the parallel B1 ranching scheme in Machakos, and both which saw rampant overgrazing on their borders in the following years as desperate owners sought any available resources for their stock. Their desperation reached a head in 1961 following the fourth consecutive year of poor rains; the failure of the long rains between March and June created acute drought conditions across the region, and the remaining watered lands in Kitui became "scarce and dangerously overgrazed." 80 The drought forced owners to seek any available oasis, migrating their stock further and further afield into open lands in Galole and Garissa in search of grazing and water, bringing them into direct competition and conflict with pastoralists from across the colony suffering similar paucities. ${ }^{81}$ Much closer to home, however, the barrier between the reserve and the B2 the western edge of the district was slowly collapsing under the weight of need, and the proverbial breaking of the dam. While trespassers had been trickling into the region over the previous three years, the number first became a stream, and then a wave.

51 In September 1961, some 20,000 head of cattle flooded across the border and into the B2 from surrounding locations in Kitui and Machakos..$^{82}$ The stock that arrived quickly pushed their way across the area, destroying waterpoints and denudating the land almost overnight, leaving both the state and Kitui stockholders in the area outraged. Deposits of silt and mud clogged the subsurface dams, and vandals deconstructed pumping stations to sell for scrap or fodder. ${ }^{83}$ The weight of destruction wrought on the state's plans led them to shutter three boreholes completely to avoid "further wanton damage." ${ }^{84}$ In the south of the region, trespassers felled and burned acacia trees for charcoal, threatening soil erosion. Within the breeding centre, the heartland of the state's stock improvement and sales endeavour, the 16 Sahiwal bulls were threatened 
by a combination of theft and disease. The centre and the herds that passed through underwent weekly dipping for tick control and the breakdown of order threatened the rampant spread of tickborne diseases, while the arrival of undipped stock threatened not only the bulls themselves but all 187 calves residing there. J. R. Stephens, the Livestock officer, recommended the calves and heifers be returned to their owners in the reserves and that the bulls be sold. He considered their chances of survival extremely remote without mandated tick control, a degree of protection that the state could not offer as their authority of the land dissolved. ${ }^{85} \mathrm{He}$ advised that the remaining fee-paid stock and the bulls be moved to the only remaining watered enclosure in the scheme, where they could be overseen by a reduced number of staff until all trespassing stock had been evicted. These defensive manoeuvres proved fruitless however, as the Sahiwal bulls were soon stolen by vandals. ${ }^{86}$ The scale of destruction appeared so bad that it appeared "doubtful if it could ever be resuscitated without strong action to throw out the trespasser." ${ }^{\text {7 }}$

The permeability of the western boundary inspired Kitui stockholders to assert their authority over what was considered to be Kitui lands. Of the 436 stockowners to have had their cattle accepted into the area at the outset of 1961, a mere 15 had paid their fees while the remainder bluntly refused. For those stockowners, it seemed nearly absurd to be charged for land that was now being destroyed by non-fee paying Machakos Kamba, and Stephens considered it deeply unethical to take the 421 abstentionists to court. ${ }^{88}$ In total, illegal trespass cost the scheme close to Shs 54,000, and the outlook appeared so bleak that Stephens advised the project be shut down in its entirety until the land had recovered and a mechanism implemented to compel Kitui stockowners to pay their fees. ${ }^{89}$ Such was the financial shortfall that the Kitui Agricultural Committee felt it improper for the African District Council to meet its loan repayments to the government for loan repayments of $£ 704$ for the B2 Scheme, as well as a $£ 400$ repayment for their share of the Yatta Furrow financing. ${ }^{90}$ Although financial concerns played a major part in this decision, the Committee also considered that the government had "failed to take adequate, or in fact any, steps to evict the illegal trespass of... Machakos stock which had caused the present catastrophic situation on the Yatta. ${ }^{91}$ Further, the committee endorsed the proposal from District Commissioner Galton-Fenzi that a committee be set up consisting of B2 Graziers, ADC members, and the district's Legislative Council Members; the committee were to report on the viability of the scheme moving forward, and the level of localized support for the grazing scheme..$^{92}$ Crucially, the committee would contain members from each of the locations surrounding the project, a critical inclusion given the localized antipathy towards the scheme's incarceration of essential watering and grazing grounds.

However even before these proposals could be acted upon, climate conditions served to further undermine the viability of grazing proposals in the region. While it had been drought that precipitated the unrestrained trespass of stock into the B2, the short rains at the end of 1961 washed away any hope of repair and progress. Over forty-two inches of rain fell between October and December in the District, a volume that amounted to the annual average in the prior three years. ${ }^{93}$ Although the rains provided relief to drought-stricken farmers and led to the outmigration of Machakos trespassers from the B2, the costs of the deluge far outweighed these positives. Rainfall across the country had led to widespread floods and destruction across the eastern portion of the nation, and these implications were felt acutely in Kitui as the raging waters damaged properties, dams, and townships. The Kenyan Government required that all districts 
provide information as to the damage, in order to spur the British state into reconstructive action. ${ }^{94}$ For Kitui, this meant emergency relief works to repair dams and roads that had been washed away by the floods of late 1961. The unprecedented damage, the Agricultural Committee claimed, had occurred not simply because of the heavy rains, but also the behaviour and incompetence of local Kamba in the district. Ever since dam work had been removed from communal labour regulations in 1958, the committee had consistently claimed that the community were failing to take adequate measures to protect dam projects, and were not being proactive in their maintenance. ${ }^{95}$ As a result, the grazing of cattle near to the dams had eroded their banks, while spillways "had been allowed to become choked with weeds and could not cope with the overflow." ${ }^{6}$ Given the Committee's view that these failures had been largely selfinflicted the Committee refused to fund the repair of the communal dams, believing the money to be unjustified "in view of the largely uncooperative attitude of the local people" in the past. ${ }^{97}$ However, this perspective fails to recognize the nature of colonial water policy at large that left the majority of resources restricted to the B2 area, and those within the locations reliant upon unpaid communal labour despite the existence of a national framework of water management infrastructure that existed for this very purpose.

Within the B2 Yatta, the state's remedial approach proved to be equally tepid. By March 1962 the area continued to be inundated with illegal Machakos and Kitui stock, and owners proved fully unwilling to cooperate with the development committee to root them out. Ear-marking was proposed as a means of rooting out illegal graziers, but the plan was uniformly rejected given that it would have enforced the payment of fees on what was now a defunct project.98 The state went so far as to reject the graziers' compromise of a reduction of fees, and began to pursue legal action against trespassers through ADC and judicial frameworks. Although refusals to pay certainly fit into a wider regional and national atmosphere of non-cooperation driven by the coming of uhuru, in this case in Ukambani resistance fit a longer-term narrative of resource access and belonging. ${ }^{99}$ Environmental and ecological pressures had combined to generate a situation whereby the state's attitude towards land and population management became untenable. Making access to water and good grazing contingent on financial strength had proven feasible during periods of relative abundance thanks to the presence of dominant stock owners and equilibrium in the reserves. However, the unpopularity of resource exclusion meant that any opportunity to circumvent the state's control of the B2 was taken with enthusiasm and would not be returned. The question of access and trespass thus became a waiting game throughout 1962, with graziers aware of impending independence and the state vainly projecting a figment of authority.

For a time, the status quo that this engendered brought some stability. Enforced eartagging had succeeded in weeding out Machakos stock, while fee-paying Kitui stock began to arrive. The District Livestock officer even suggested further proposals to improve the viability of the project that included the provision of bomas for housing stock, as well as free inoculations. ${ }^{100}$ However, the viability of these suggestions were curtailed by the growing realization of Kenyan independence. With seemingly little warning the central government degazetted the B2 in late 1962, converting the entire region into a native land unit as opposed to crown lands. ${ }^{101}$ In effect, this ceased all government control of grazing in the region, and broke down any distinction between the area and the surrounding locations. Any continuation of the scheme as a delineated 
and managed project thus necessitated an amendment to the ADC rules, which was forthcoming in March 1963. In practice, the change in designation meant very little; control of the scheme had been delegated to the ADC since 1952, meaning the transition simply moved ultimate authority from Nairobi to Kitui. Nonetheless, there is symbolic meaning in this change. Rather than existing as part of a centralized network of land management and water schemes the B2 passed into the hands of local government, in effect making its management the concern of a locally elected body of stockholders and politicians. As the transition to uhuru accelerated, the B2 became symbolic of the transfer of power that disposed of the colonial state's apparent belief in the greater good of modernist planning, towards a more decentralized approach to land management and access arrangements. That the terms of access changed little had much to do with the continuities in the ADC's composition, but nonetheless the B2 continued as a grazing scheme open to any willing to take a licence. ${ }^{102}$

In the following postcolonial years however, the area would transition from a paid grazing scheme to its current form as a cooperative ranching endeavour, defined by the mutual ownership of cattle and the distribution of fees and profits amongst the collective. ${ }^{103}$ The Committee hoped that a cooperative project would create a sense of ownership amongst graziers sceptical of the benefits of paid grazing, leading to communal responsibility and an improved landscape while also paying for the maintenance of water resources in the area. ${ }^{104}$ On the B2, this ultimately led to the land being leased from the district on a 999 year lease, and the herd owned collectively (International Livestock Centre for Africa (Kenya), 1979). By 1979, the ranch encompassed over 22,000 hectares, and was made up of 548 owners. Under this arrangement, water and land improvement policies are undertaken from the funds of the cooperative partnership, ensuring equities in access and extension amongst all members

\section{Conclusions}

The B2 Yatta stands as an exercise symptomatic of Britain's failed development goals in Kenya more generally. The project was defined by tenuous and ever-changing policies based upon apocryphal and culturally inappropriate understandings of Kamba land and livelihoods (of the type described by Tignor, Osborne, and others), all of which contributed to widespread ecological decay in the pursuit of environmental and territorial control. By providing water resources to an exclusive region while deliberately neglecting those in the reserves, the state attempted to enforce territorial control by weaponizing the precarious ecology of the Yatta. Although the B2 grazing scheme started on relatively firm (if flawed) foundations thanks to the clear priority of lessening land pressure in the reserves, the shift towards an explicitly profit-making ranching scheme served to close the B2 to all except those willing to accept state sanctions. As a result, the state's neglect of the reserves can be considered a deliberate attempt to destroy local environmental conditions in the pursuit of their wider social and economic goals, as the protection of watering and grazing grounds behind a financial barrier served to exacerbate overcrowding and consumption in the reserves.

58 As such, this article argues that the destruction of the colonial B2 project in Kitui occurred due to an ecological crisis of the state's own making on a regional scale, having directed their policies towards profits rather than people. Rather than investing 
and distributing water to the community at large, it was instead deemed to be a privileged granted only to the wealthy or the acquiescent. The episode thus reveals the critical flaws inherent in the state's development ideology more generally that saw an initially useful, if defective, grazing scheme replaced by increasingly coercive methods that ensured the death and dispersal of stock across the region. The loggerhead between this ideology and the economic and material needs of the people made conflict inevitable, a conflict that was eventually decided by shifting environmental conditions.

\section{BIBLIOGRAPHY}

Adams, W. M. 1992. Wasting the Rain: Rivers, People, and Planning in Africa. London: Earthscan.

Ambler, C. 1985. "Population Movement, Social Formation and Exchange: Central Kenya in the Nineteenth Century." International Journal of African Historical Studies 18(2): 201-227.

Amutabi, M. 2013. Environment, Power, and Development in Kenya. Nairobi: The Catholic University of Eastern Africa.

Anderson, D.M., and D.A. Johnson. 1991. The Ecology of Survival Case Studies from North-east African History. Boulder: Westview Press.

Anderson, D. 2002. Eroding the Commons: The Politics of Ecology in Baringo, 1890-1963. Oxford: James Currey.

Chambers, R. and J. Morris. 1973. Mwea: An Irrigated Rice Settlement in Kenya. Munich: Weltsforum Verlag

Conte, C. 1999. "Colonial Science and Ecological Change: Tanzania's Mlalo Basin, 1888-1946." Environmental History 4(2): 220-44. https://doi.org/10.2307/3985304.

Hardin, G. 1968. “The Tragedy of the Commons.” Science 162(3869): 1243-48. http://doi.org/ 10.1126/science.162.3859.1243.

Herskovits, M. 1926. “The Cattle Complex in East Africa." American Anthropologist 28(1): 230-272; 28(2): 361-388; 28(3): 494-528; 28(4): 633-664. https://doi.org/10.1525/aa.1926.28.1.02a00050; https://doi.org/10.1525/aa.1926.28.2.02a00030; https://doi.org/10.1525/aa.1926.28.3.02a00030; https://doi.org/10.1525/aa.1926.28.4.02a00040.

Hoag, H. 2013. Developing the Rivers of East and West Africa An Environmental History. London: Bloomsbury.

Hoppe, K. 2003. Lords of the Fly: Sleeping Sickness Control in British East Africa 1900-1960. Westport CT: Praeger.

International Livestock Centre for Africa (Kenya). 1979. District Ranch Development Briefs. Nairobi. URL: https://hdl.handle.net/10568/4462.

Johnson, D.H. and Anderson, D. (eds). 1991. The Ecology of Survival Case Studies from North-east African History. Boulder: Westview Press. 
Kjekshus, H. 1993. Ecology Control and Economic Development in East African History: The Case of Tanganyika 1850-1950. Dar es Salaam: Mkuki na Nyota; Kampala: Fountain Publishers; Nairobi: EAEP; Athens: University of Ohio Press; London: James Currey.

Leach, M., and R. Mearns, eds. 2003. The Lie of the Land: Challenging Received Wisdom on the African Environment. Oxford: James Currey.

Mackenzie, F. 1998. Land, Ecology, and Resistance in Kenya, 1980-52. Portsmouth (NH): Heinemann. Maher, C. 1937. Soil Erosion and Land Utilization in the Ukamba Reserve. Machakos.

McKittrick. M. 2015. “An Empire of Rivers: The Scheme to Flood the Kalahari, 1919-1945.” Journal of Southern African Studies 41 (3): 485-504. https://doi.org/10.1080/03057070.2015.1025339.

Osborne, M. 2014. Ethnicity and Empire in Kenya: Loyalty and Martial Race Among the Kamba, c. 1800 to the Present. Cambridge: Cambridge University Press. https://doi.org/10.1017/CBO9781107447714.

Russell, L., ed. 2001. Colonial Frontiers: Indigenous-European Encounters in Settler Societies. Manchester: University of Manchester Press.

Scoones, I., ed. 1995. Living with Uncertainty: New Directions in Pastoralist Development in Africa. London: Practical Action Publishing.

Shanguhyia, M. 2015. Population, Tradition \& Environmental Control in Kenya, 1920-1963. Rochester (NY): University of Rochester Press.

Showers, K. 2005. Imperial Gullies: Soil Erosion and Conservation in Lesotho. Athens (OH): Ohio University Press.

Spear, T. 1997. Mountain Farmers: Moral Economies of Land and Development in Arusha and Meru. Oxford: James Currey.

Tignor, R. 1971. "Kamba Political Protest: The Destocking Controversy of 1938." African Historical Studies 4(2): 237-251. https://doi.org/10.2307/216416.

Tilley, H. 2011. Africa as a Living Laboratory: Empire, Development, and the Problem of Scientific Knowledge, 1870-1950. Chicago: University of Chicago Press.

Todd, J. 1995. Colonial Technology. Science and the Transfer of Innovation to Australia. Cambridge: Cambridge University Press.

Van Zwanenberg, R. 1975. Colonial Capitalism and Labour in Kenya 1919-39. Kampala: East African Literary Bureau.

\section{NOTES}

1. The definition of stock is generally fluid over time. The Kenyan state at this time defined it as including cattle, sheep, goats, and pigs.

2. Their fears are reflective of wider scientific and agricultural policy in Africa. These sentiments are most fully explicated Africa as a Living Laboratory by Tilley (2011).

3. Ukambani is generally defined as the entirety of Kamba land in the region, encompassing both Kitui and Machakos.

4. The adaptive function within tribal environmental responses has also been expounded upon by Martin Shanguhyia (2015), Chris Conte (1999) and Maurice Amutabi (2013). 
5. KNA DC/KTI/2/1. C. A. Cornell, Handing Over Report: Kitui District, 15 July 1942, 7.

6. KNA DC/KTI/1/1/16. DC Kitui District, Kitui Annual Report 1959, 14.

7. KNA DC/KTI/3/12/4. Kitui Yatta Land Utilization Scheme, 26 July 1949.

8. Ibid.

9. KNA BV/14/244. Kitui (B2) Yatta Grazing Scheme, n. d., 1.

10. KNA DC/KTI/2/1., R. D. F. Rylands, Handing Over Report-Kitui District, August $1947,9$.

11. Ibid.

12. BOD. MSS. Afr. S. 545. Telegram from G. R. B. Brown to PC Nyeri, 1 January 1946, 1.

13. DC/KTI/3/12/4. W. Kelly, The Yatta B2 Scheme, 1949, 2.

14. Ibid., 2.

15. DC/KTI/3/12/4. Kitui Yatta Land Utilization Scheme, 26 July 1949, 1.

16. DC/KTI/3/12/4. PC Central Province, Kitui B2 Yatta Scheme, 31 January 1950.

17. DC/KTI/3/12/4. Kitui Yatta Scheme, 18 February 1950, 1.

18. DC/KTI/3/12/4. Estimates B2 Yatta Land Utilization Scheme, 26 July 1949, 1.

19. DC/KTI/3/12/4. Kitui Yatta: report on borehole investigations, June 1950, 2.

20. Ibid., 3.

21. PDA/KTI/3/2/31. J. R. Stephens, Report on Kitui District, 1960, 3.

22. PDA/KTI/3/2/31. Five Year Plan-Kitui District, 12 May 1954, 13.

23. PDA/EBU/1/133 Memorandum on the Machakos Yatta, 4 June 1960, 3.; DC/KTI/ 3/2/32. Minutes of the Kitui District Agricultural Committee, 2 February 1959, 3.

24. Bod. MSS. Afr. S. 787/4. D. J. Penwill, Machakos District Development Plan, 2 October 1953, 2.

25. $\mathrm{PC} / \mathrm{NGO} / 1 / 2 / 18$. Office of the Land Utilisation and Settlement Board, Populations and Land, Central Province, n.d., 2.

26. Ibid., 3.

27. Kenya (Colony and Protectorate) Land Commission, Report of the Kenya Land Commission (London, 1933), 369.

28. PDA/EBU/1/133. Memorandum on the Machakos Yatta, 1960, 1.

29. Bod. MSS. Afr. S. 787/4. Machakos District Development Plan, 10.

30. Ibid., 12.

31. Ibid., 14.

32. Although primarily benefiting the B1 Yatta, the Furrow pushed water into the Mwita Syano thus offering benefits to both sides of the district line. "Memorandum on the Machakos Yatta," 2.

33. DC/KTI/2/1. P.S. Osborne, Handing Over Report-Kitui District 1944, 2.

34. DC/KTI/1/1/5. District Commissioner Kitui, Kitui District Annual Report 1945, 15.

35. PC/NGO/1/2/18. W. M. Kelly, Kitui B.2 Yatta Scheme-Rules, 22 May 1950.

36. PDA/218. Minutes of a Meeting of the Kitui Local Native Council, August 27 and 28 $1947,5$.

37. Ibid., 5 . 
38. PDA/218. Minutes of a Meeting of the Kitui Local Native Council, November 1-3 $1949,2$.

39. PDA/218. Minutes of a Meeting of the Kitui Local Native Council, May 1- June 3 1948, 5 .

40. Government Notice 1186 of 11/11: The Crown Lands (Kitui B2 Yatta) (Land Utilisation) Rules, 1952.

41. $\mathrm{PC} / \mathrm{NGO} / 1 / 2 / 18$. Extract from Annual Report of the Acting Provincial Agricultural Officer for Southern Province, 1954.

42. DC/KTI/3/12/4. E. Hall, B2 Yatta Scheme, 1955, 1.

43. DC/KTI/3/12/4. Telegram to PC Southern Province, Development Policy: Kitui District, 23 May 1955.

44. DC/KTI/3/12/4. African District Council Loans, 16 May 1956.

45. Fees also gave the Agricultural Officer the means to extend bush-burning in the southern portion of the B2. Previously, the extension of grazing this area had relied on the incursions of stock owners, but the abundance of water in the region led to fears that unrestrained grazing would lead to the denudation of the landscape.

46. DC/KTI/3/12/4. E. Hall, B2 Yatta Scheme, 18 March 1955, 1.

47. DC/KTI/3/12/4. Baraza Held at Kitui-Yatta Stock Owners, 17 August 1953, 1.

48. DC/KTI/3/12/4. E. Hall, Cattle Staging on B2 Yatta, 21 April 1955.

49. DC/KTI/3/12/4. Asst. Ag. Off., Kitui Development Policy, Livestock and Overgrazing, 10 June 1955. 1.

50. DC/KTI/3/12/4. Asst. Ag. Off., Kitui Development Policy, 1.

51. MW/2/6. Kitui Development Policy: Livestock, 10 June 1955, 1.

52. MW/2/6. Memo from the Assistant Agricultural Officer to the District Commissioner Kitui, 5 July 1955.

53. Bod. MSS. Afr. S. 545. Telegram from G. R. B. Brown to PC Nyeri, 1 January 1946, 1.

54. Telegram from G. R. B. Brown to PC Nyeri, 1 January 1946, 2.

55. MW/2/6. Estimated Revenue and Expenditure: Cattle Ranching Schemes B2 Yatta, n. d.

56. Ibid., 2.

57. MW/2/6. S. Meadows, Development Policy in Kitui District, 2 July 1955.

58. MW/2/6. S. Meadows, Bush Clearing, 13 July 1955.

59. MW/2/6. Meadows, Bush Clearing, 24 October 1955.

60. MW/2/6. Minutes of the Kitui District Agricultural Committee, 11 August 1956, 3.

61. PDA/KTI/3/2/31. Kitui District Development Report, 5 October 1960, 3.

62. Ibid., 3-4.

63. $\mathrm{DC} / \mathrm{NGO} / 1 / 9 / 14$. Minutes of the Agriculture, Veterinary, and Forest Committee of the Kitui ADC, 27 June 1960, 1.

64. DC/KTI/1/1/16. R. J. Hickson-Mahony, Kitui District Annual Report 1959, 14.

65. DC/KTI/1/1/17. District Commissioner Kitui, Kitui District Annual Report 1960, 1.

66. DC/NGO/1/9/14. Minutes of the Meeting of the Kitui African District Council, 20 July 1960,4 . 
67. Ibid., 3.

68. DC/KTI/1/1/17. Kitui District Annual Report 1960, 11.

69. PDA/EBU/1/133. P. G. Perry, Progress Report on the Matuu Settlement Scheme, 29 January 1958, 1.

70. PDA/EBU/1/133. Memorandum on the Machakos Yatta, 3.

71. PDA/EBU/1/133. L. H. Brown, Memorandum on the Yattas," 20 December 1956, 1.

72. PDA/EBU/1/133. District Agricultural Officer, Yatta Plateau, 12 July 1957, 2.

73. PDA/EBU/1/133. Report on a Visit to the Machakos B1 Yatta, 1956, 3.

74. Ibid., 1.

75. PDA/EBU/1/133. B1 Yatta Quarterly Report, 4 April 1958, 2.

76. PDA/EBU/1/133. C. P. Wadden-Cave, Memorandum on the Yattas, February 81957 , 2.

77. PDA/EBU/1/133. B1 Yatta Quarterly Report, 3 July 1959, 1.

78. PDA/EBU/1/133. Stock Figures and Licence Holders on Yatta Plateau Related to Settlements, Appx. B. 19 October 1959.

79. Ibid.

80. DC/KTI/1/1/18. J. F. Johnston, Kitui District Annual Report 1961, 1.

81. Ibid., 1.

82. DC/KTI/3/2/32. The B2 Yatta Grazing Scheme, 20 October 1961. 1.

83. DC/KTI/3/2/32. The B2 Yatta Grazing Scheme, 16 October 1961, 1.

84. Ibid.

85. Ibid.

86. Kitui District Annual Report 1961, 15.

87. Ibid.

88. DC/KTI/3/2/32. The B2 Yatta Grazing Scheme, 20 October 1961.

89. DC/KTI/3/2/32. The B2 Yatta Grazing Scheme, 16 October 1961, 2.

90. DC/KTI/3/2/32. Minutes of a Meeting of the Kitui Agricultural District Committee, 3 November 1961, 3.

91. Ibid.

92. DC/KTI/3/2/32. Minutes of a Meeting of the Kitui Agricultural District Committee, 3 November 1961, Appendix B, 1.

93. Kitui District Annual Report 1961, 1.

94. DC/KTI/3/2/32. Telegram from P. M. Gordon to District Commissioner Kitui, 8 January 1962.

95. DC/KTI/3/2/32. Meeting of the Executive Committee of the District Agricultural Committee, 11 January 1962.

96. Ibid.

97. Ibid.

98. $\mathrm{DC} / \mathrm{KTI} / 3 / 2 / 32$. Minutes of the Meeting of the Kitui District Agricultural Committee, 30 March 1962, 1.

99. Colonial administrators consistently used the term uhuru in place of independence. 
100. $\mathrm{DC} / \mathrm{KTI} / 3 / 2 / 32$. Minutes of the Meeting of the Kitui District Agricultural Committee, 3 December 1962, 2.

101. DC/KTI/1/1/19. J. F. Johnston, Kitui District Annual Report 1962, 10.

102. PDA/EBU/1/16. The African District Council of Kitui (Grazing and Pound) By-laws, 1963.

103. $\mathrm{DC} / \mathrm{KTI} / 3 / 2 / 32$. Minutes of the Meeting of the Kitui District Agricultural Committee, 22 October 1963, 2-3.

104. DC/KTI/3/2/32. Minutes of the Meeting of the Kitui District Agricultural Committee, 19 July 1963, 2.

\section{ABSTRACTS}

This research paper historicizes colonial water management policies in Kitui, Kenya, under the British colonial state. British development policy weaponized water shortages in order to enforce destocking amongst Kamba populations, leading to a wide array of ecological challenges. The paper contends that the state's use of water as a tool of population management and land improvement was based on flawed ideas of society and environment that ultimately contributed to the demise of the area's major betterment project, the B2 Yatta Scheme.

\section{INDEX}

Geographical index: Kenya

\section{AUTHOR}

JAMES PARKER

Northeastern University, Boston (MA). 